\title{
Prior lactose glycation of caseinate via the Maillard reaction affects in vitro activities of the pepsin-trypsin digest toward intestinal epithelial cells
}

\author{
X. P. Wang and X. H. Zhao' \\ Key Laboratory of Dairy Science, Ministry of Education, Northeast Agricultural University, Harbin 150030, China
}

\section{ABSTRACT}

The well-known Maillard reaction in milk occurs between lactose and milk proteins during thermal treatment, and its effects on milk nutrition and safety have been well studied. A lactose-glycated caseinate was prepared via this reaction and digested using 2 digestive proteases, pepsin and trypsin. The glycated caseinate digest was assessed for its in vitro activities on rat intestinal epithelial cells in terms of growth proliferation, anti-apoptotic effect, and differentiation induction using caseinate digest as reference, to verify potential effects of the Maillard reaction on these activities of caseinate digest to the cells. Two digests had proliferative and anti-apoptotic effects, and reached the highest effects at $0.02 \mathrm{~g} / \mathrm{L}$ of digest concentration with treatment time of $24 \mathrm{~h}$. In comparison with caseinate digest, glycated caseinate digest always showed weaker proliferative (5.3-14.2\%) and anti-apoptotic (5.9-39.0\%) effects, and was more toxic to the cells at $0.5 \mathrm{~g} / \mathrm{L}$ of digest concentration with treatment time of $48 \mathrm{~h}$. However, glycated caseinate digest at 2 incubation times of 4 to 7 $\mathrm{d}$ showed differentiation induction higher than caseinate digest, as it could confer the cells with increased activities in lactase (16.3-26.6\%), sucrase (22.4-31.2\%), and alkaline phosphatase (17.4-24.8\%). Transmission electron microscopy observation results also confirmed higher differentiation induction of glycated caseinate digest. Amino acid loss and lactose glycation partially contributed to these decreased and enhanced activities of glycated caseinate digest, respectively. The Maillard reaction of caseinate and lactose is thus shown in this study to have effects on the activities of caseinate digest to intestinal epithelial cells.

Key words: caseinate, lactose, Maillard reaction, intestinal epithelial cell

\footnotetext{
Received December 19, 2016.

Accepted March 8, 2017.

${ }^{1}$ Corresponding author: zhaoxh@neau.edu.cn or xhzhao63@sina. com.cn
}

\section{INTRODUCTION}

A classic reaction between proteins/peptides and reducing sugars known as the Maillard reaction is very important, because this reaction occurs during thermal processing and thus induces some effects on nutrition and quality of processed foods (van Boekel, 1998). This reaction is a complicated system containing several parallel and consecutive reactions, and all reaction stages can occur simultaneously (Morales and Jiménez-Pérez, 1998). Regarding milk and milk-based foods, this reaction is unavoidable because all these foods contain both reducing sugar (lactose) and proteins (casein and whey proteins). More importantly, this reaction principally occurs between lactose and the Lys residues in casein, because the Lys residues in casein are more reactive than those in whey proteins (Mehta and Deeth, 2016). The extent of this reaction depends on thermal procedures and storage conditions (Arena et al., 2011). In the first stage of this reaction, lactose via its reducing end (glucose units) reacts with casein, leading to the formation of the Schiff's base (lactosyl-Lys) and subsequently to the formation of the Amadori products referred to as lactulosyl-Lys (Bhatt et al., 2014). Severe thermal treatment can induce forthcoming reactions in terms of dehydration of the conjugated lactose moieties, condensation of amino compounds, and degradation of proteins, giving rise to the formation of the advanced glycation end products (AGE; Davidek et al., 2002). Connecting reducing sugars with proteins via this reaction will generate protein-sugar conjugates (i.e., glycated proteins). This reaction is thus studied for its potential application in protein modification in recent years (Wang and Ismail, 2012). Various reducing sugars such as allose, galactose, and glucose have been used to glycate proteins in an attempt to alter functional and anti-oxidative properties of proteins (Sun et al., 2006; Chevalier et al., 2011; Dong et al., 2012).

The Maillard reaction can have several adverse effects on processed foods, which have been verified in the past studies. This reaction leads to decreased nutritional value of proteins, because this reaction partially reduces bioavailability of the essential AA especially 
Lys (Siciliano et al., 2013). In vitro digestibility of the glucose-modified casein during a simulated gastrointestinal digestion is reduced with the increases of the Lys modification degree (Hellwig et al., 2014). Other in vitro and in vivo studies also demonstrate that Maillard reaction products, even Amadori products, are less readily digested than unglycated proteins in the small intestine because the modified Lys residues are no longer recognized by the gastrointestinal proteases (Erbersdobler and Faist, 2001; Corzo-Martínez et al., 2013; Teodorowicz et al., 2014). The diets rich in Maillard reaction products (especially the AGE), therefore, show decreased protein digestion (Seiquer et al., 2006). The Maillard reaction products (early glycated proteins, AGE, or both) have some flaws from a health point of view, such as accelerating oxidative stress and inflammation, altering glucose regulation (Schalkwijk and Miyata, 2012; Arena et al., 2014), and increasing endogenous AGE formation (Henle and Miyata, 2003). On the other hand, this reaction has also been assessed for its positive effects on protein functionalities, even body health. The results demonstrate that proteincarbohydrate conjugates with minimal cross-linking possess higher solubility, thermal stability, and anti-oxidation (Silván et al., 2011; Wang and Ismail, 2012; Seo et al., 2014). In addition, the Amadori-type conjugates are verified to have bifidogenic effects by turning nonbifidogenic sugars (such as galactose) into bifidogenic adducts (Corzo-Martínez et al., 2013). However, special attention should be paid to other potential effects of Maillard reaction products on body health, based on the fact that glycated proteins or protein-sugar conjugates are commonly found in processed foods (van Boekel, 1998; Pischetsrieder and Henle, 2012) or especially applied in several fields of food science, nutrition, and medical biochemistry in recent years (Erbersdobler and Faist, 2001). Intake of these glycated proteins or conjugates into the gastrointestinal tract of the body will generate respective glycated protein digests via the action of digestive proteases. It is reasonable that intestinal epithelial cells in the mucosal surface have opportunity to contact these digests. Whether these digests have increased or decreased effects on intestinal epithelial cells, in comparison with normal protein digests, is absolutely important to the body but still remains unclear to us.

The gut is the gateway of nutrient intake that fuels the whole body, and healthy intestine ensures a long life (Losso, 2015). Intestinal epithelial cells proliferate rapidly, participate in both nutrient absorption and immune activation (Graves et al., 2014), undergo about $10^{11}$ mitoses per day (Potten et al., 1992), and have a complete turnover every 24 to $96 \mathrm{~h}$ (Peterson and Artis, 2014). This rapid and dynamic turnover is highly regulated and critically controlled by numerous intracellular and extracellular factors including the presence of dietary components, gut peptides, and RNA-binding proteins (Chung et al., 2014). From a chemical point of view, the digests from glycated proteins or conjugates of the Maillard reaction type are partially different from these from unglycated proteins, due to the conjugation of the reducing sugars. Reducing sugars are covalently connected into the Lys residues and cannot be released by the action of digestive proteases. In addition, this connection modifies the Lys residues and especially impairs tryptic sensitivity of the Lys residues. All these might confer the glycated protein digests with different structures as well as increased or decreased activities, in comparison with normal protein digests. Both in vitro and in vivo investigation are thus needed to verify the potential effects of protein glycation on the activities of digests on intestinal epithelial cells.

In this study, a lactose-glycated caseinate was prepared using lactose and caseinate via the Maillard reaction and then digested by 2 digestive proteases (pepsin and trypsin). The obtained digest was assessed for its capacities in terms of proliferative regulation, antiapoptotic effect (reflected as apoptotic prevention), and differentiation induction using rat intestinal epithelial (IEC-6) cells as the cell model. Caseinate digest was used as a control and also evaluated for these capacities. The aim of this study was to provide scientific evidence for other effects of the Maillard reaction on food proteins, that is, to assess if protein glycation has negative or positive effects on protein's activity toward intestinal epithelial cells.

\section{MATERIALS AND METHODS}

\section{Materials}

Caseinate, D-lactose, dispase II (EC 3.4.24.4) with measured activity of 0.85 units $(\mathrm{U}) / \mathrm{mg}$, glucose assay kit, bovine insulin, and Dulbecco's modified Eagle's medium were purchased from Sigma-Aldrich Co. Ltd. (St. Louis, MO). Pepsin (EC 3.4.23.1) and trypsin (EC 3.4.21.4) with measured activities of 40 and $120 \mathrm{U} /$ $\mathrm{mg}$, respectively, were bought from Beijing Aoboxing Biotechnologies Inc. (Beijing, China). Camptothecin and sodium pyruvate were purchased from Aladdin Industrial Inc. (Shanghai, China). Fetal bovine serum was purchased from Wisent Inc. (Montreal, Quebec, Canada). Matrigel basement membrane matrix was purchased from Corning Glass Works (Bedford, MA). Trypsin-EDTA, dimethyl sulfoxide, and PBS were purchased from Solarbio Science and Technology Co. Ltd. (Beijing, China). The EnzycChrom Galactose Assay Kit was purchased from BioAssay Systems (Hayward, 
CA). Cell Counting Kit-8 (CCK-8) was purchased from Dojindo Molecular Technologies Inc. (Kyushu, Japan). Annexin V-FITC/PI Apoptosis Detection Kit, Alkaline Phosphatase Assay Kit, and Bicinchoninic Acid Protein Assay Kit were bought from Beyotime Institute of Biotechnology (Shanghai, China). The water used in this study was ultrapure water generated from Milli-Q Plus (Millipore Corporation, New York, NY). Other chemicals used were analytical grade.

\section{Preparation of Glycated Caseinate and 2 Digests}

A reported reaction system (Rufián-Henares et al., 2006) was used to prepare lactose-glycated caseinate with minor modifications. In brief, the reaction mixture was prepared with caseinate $(50 \mathrm{~g} / \mathrm{L})$ and lactose $(80 \mathrm{~g} / \mathrm{L})$ in ultrapure water at $\mathrm{pH} 6.8$, followed by a reaction at $100^{\circ} \mathrm{C}$ for $3 \mathrm{~h}$. After isoelectric precipitation and 3 isoelectric washings at $\mathrm{pH} 4.5$, the collected precipitate (lactose-glycated caseinate) was freeze-dried and ground into powder.

Protein digestion was carried out as previously described (Tang et al., 2009) with some modifications. Caseinate (or glycated caseinate) was dispersed in 0.1 $\mathrm{mol} / \mathrm{L}$ of $\mathrm{HCl}$ with a final protein concentration of 50 $\mathrm{g} / \mathrm{L}(\mathrm{pH} 1.9)$, and digested by pepsin $(800 \mathrm{U} / \mathrm{g}$ of protein) for $1 \mathrm{~h}$ at $37^{\circ} \mathrm{C}$. The mixture was adjusted to 7.0 , heated at $100^{\circ} \mathrm{C}$ for $5 \mathrm{~min}$ to stop the peptic digestion, followed by freeze-drying and grinding to obtain peptic digest powder. The peptic digest powder was then mixed with trypsin $(7 \mathrm{kU} / \mathrm{g}$ of protein) and ultrapure water to achieve final protein concentration of $50 \mathrm{~g} / \mathrm{L}$, and subjected to tryptic digestion at $\mathrm{pH} 7.0$ and $37^{\circ} \mathrm{C}$ for $2 \mathrm{~h}$. The tryptic digestion was terminated at $100^{\circ} \mathrm{C}$ for $5 \mathrm{~min}$. The mixture was centrifuged at $5,000 \times g$ for $10 \mathrm{~min}$ at $4^{\circ} \mathrm{C}$, freeze-dried, and ground into powder. The prepared pepsin-trypsin digests of caseinate and glycated caseinate were all stored at $-20^{\circ} \mathrm{C}$ before use. Two digests were dissolved in the medium at various digest concentrations and then used in cell experiments.

\section{Chemical and Electrophoretic Analyses}

Protein contents of the samples were assessed using the Kjeldahl method and conversion factor of 6.38 (AOAC International, 2005). Amino acid compositions ( $\mathrm{g} / \mathrm{kg}$ of protein) were analyzed by the Heilongjiang Provincial Academy of Agricultural Sciences, using an automated AA analyzer (L-8800, Hitachi Co., Ltd., Tokyo, Japan) and the recommended procedure provided by the instrument manufacturer.

Contents of bound lactose of the samples were assayed as following. The samples were hydrolyzed by 2 $\mathrm{mol} / \mathrm{L}$ of trifluoroacetic acid (TFA) at $100^{\circ} \mathrm{C}$ for $4 \mathrm{~h}$ (Račaitytė et al., 2005), cooled to ambient temperature, and neutralized. The obtained hydrolysates were detected for their galactose contents as per the method of Wang and Zhao (2016), using the kit and procedure provided by the kit producer. Contents of bound lactose $(\mathrm{g} / \mathrm{kg}$ of protein) were thereby calculated using respective chemical formulae of galactose and lactose.

Sodium dodecyl sulfate-PAGE analysis was conducted as previously described (Song and Zhao, 2014), using stacking and resolving gels of 40 and $70 \mathrm{~g} / \mathrm{L}$, respectively. The stacking gels were run at $80 \mathrm{~V}$, and the separating gels were run at $120 \mathrm{~V}$. The gels were stained with Coomassie Brilliant Blue-R250 (2.5 g/L) for protein visualization. To detect the protein-sugar conjugates, the gels were also stained with Pararosaniline-Schiff reagent (Zacharius et al., 1969). Original caseinate and horseradish peroxidase (a glycoprotein) were included in this analysis as negative and positive controls, respectively. Protein markers with molecular weights of 14.4 to $97.4 \mathrm{kDa}$ were used in this analysis.

\section{Cell Line and Culture Conditions}

The IEC-6 cells were brought from the American Type Culture Collection (Rockville, MD), and cultured in medium consisting of Dulbecco's modified Eagle's medium with $10 \%$ fetal bovine serum, $1 \%$ sodium pyruvate, and $0.1 \%$ bovine insulin. The IEC- 6 cells were maintained in a humidified $37^{\circ} \mathrm{C}$ incubator with $5 \%$ $\mathrm{CO}_{2}$, and the medium was replaced every $48 \mathrm{~h}$.

\section{Assay of Cell Proliferation}

The IEC- 6 cells were seeded at a density of $2 \times 10^{4}$ cells/mL onto 96 -well plates in $100 \mu \mathrm{L}$ of medium to confluence for $24 \mathrm{~h}$, serum-starved for $12 \mathrm{~h}$, and incubated with the 2 digests at 4 digest concentrations $(0.02-0.5 \mathrm{~g} / \mathrm{L})$ for 6 to $48 \mathrm{~h}$, respectively. After incubation, $20 \mu \mathrm{L}$ of CCK-8 was added to each well, and the cells were incubated for another $90 \mathrm{~min}$. Optical density at $450 \mathrm{~nm}$ was measured by a microplate reader (BioRad Laboratories, Hercules, CA). The effect of each digest on cell proliferation was assessed via percent cell viability where the vehicle-treated cells served as $100 \%$ viability.

\section{Apoptosis Assay}

Camptothecin was used in this study to induce apoptosis of IEC-6 cells. Apoptosis induction was assayed by Annexin V-fluorescein isothiocyanate (FITC) and propidium iodide (PI) double staining methods (Bhat- 
tacharya et al., 2004). The cells were plated at $2 \times$ $10^{4}$ cells $/ \mathrm{mL}$ onto 6 -well plates in $2 \mathrm{~mL}$ of medium to confluence for $24 \mathrm{~h}$, starved for $12 \mathrm{~h}$, and incubated with 2 digests at 3 digest concentrations (0.02-0.1 $\mathrm{g} / \mathrm{L})$ for 12 to $24 \mathrm{~h}$, respectively. Serum-free medium containing camptothecin $(20 \mu \mathrm{mol} / \mathrm{L})$ was added to induce apoptosis, and the cells were incubated for $6 \mathrm{~h}$. After that, the cells were stained using the Annexin VFITC/PI Apoptosis Detection Kit consistent with the manufacturer's instructions. In brief, the cells were harvested and resuspended in $500 \mu \mathrm{L}$ of Annexin V-FITC blending buffer, and stained with $5 \mu \mathrm{L}$ of the Annexin V-FITC and $10 \mu \mathrm{L}$ of PI. The cells were kept in the dark at $20^{\circ} \mathrm{C}$ for 20 min and assayed by flow cytometry (FACS Calibur, Becton Dickinson, San Jose, CA) to discriminate the intact, early (Q4), late apoptotic (Q2), and necrotic cells. The vehicle dimethyl sulfoxide was used as control in this assay.

\section{Assays of Brush Border Membrane Enzyme Activities of Differentiated IEC-6 Cells}

The IEC- 6 cells at $5 \times 10^{5}$ cells $/ \mathrm{mL}$ in $2 \mathrm{~mL}$ of medium were plated on 35 -mm cell culture dishes coated with a thin layer of Matrigel (1:8 diluted with serumfree medium), grown to confluence for $24 \mathrm{~h}$, starved for $12 \mathrm{~h}$, and incubated with medium containing the 2 digests $(0.02-0.1 \mathrm{~g} / \mathrm{L}$ of digest concentrations) for 4 to $7 \mathrm{~d}$, respectively. The medium was replaced every $48 \mathrm{~h}$. The cells were recovered from the Matrigel by 1 $\mathrm{mL}$ of diluted dispase II (1.7 units $/ \mathrm{mL})$. The collected cells were sonicated 10 times for $6 \mathrm{~s}$ each in an ice bath, centrifuged for $5 \mathrm{~min}$ at $12,000 \times \mathrm{g}$ at $4^{\circ} \mathrm{C}$ to obtain supernatants, followed by enzyme activity measurements. Protein contents of the supernatants were determined using the bicinchoninic acid protein assay, and BSA was used as standard protein.

The supernatants were incubated at $37^{\circ} \mathrm{C}$ with 50 $\mathrm{mmol} / \mathrm{L}$ of lactose and sucrose for 60 and $30 \mathrm{~min}$, respectively. The liberated glucose was measured using the glucose assay kit (Sigma-Aldrich Co. Ltd.) according to the manufacturer's instructions (http://www. sigmaaldrich.com/content/dam/sigma-aldrich/docs/

Sigma/Bulletin/gago20bul.pdf). Lactase (EC 3.2.1.22) and sucrase (EC 3.2.1.26) activities were expressed as nanomoles of glucose/milligram of protein per minute (Buccigrossi et al., 2007). Alkaline phosphatase (EC 3.1.3.1; He et al., 1993) activity was measured using $p$-nitrophenyl phosphate as the substrate (Goldstein et al., 1971), and liberated $p$-nitrophenol was measured at $450 \mathrm{~nm}$ using the Alkaline Phosphatase Assay Kit. Alkaline phosphatase activity was expressed as milliunits per milligram of protein.

\section{Morphologic Observation of Differentiated IEC-6 Cells}

The IEC- 6 cells at $5 \times 10^{5}$ cells $/ \mathrm{mL}$ in $100 \mu \mathrm{L}$ of medium were grown on Transwell-clear polyester membranes $(3.0 \mu \mathrm{m}$ pore size) precoated with thin Matrigel (1:8 diluted with serum-free medium). Two digests at concentrations of $0.02 \mathrm{~g} / \mathrm{L}$ were used to treat the cells for 4 or $7 \mathrm{~d}$. Then, the cells were washed using PBS $(0.01 \mathrm{~mol} / \mathrm{L}, \mathrm{pH}=7.2)$. The cut membrane was pre-fixed overnight in $2.5 \%$ glutaraldehyde $(0.1 \mathrm{~mol} / \mathrm{L}$, $\mathrm{pH} 7.2$ ), post-fixed in $1 \% \mathrm{OsO}_{4}$ for $2 \mathrm{~h}$, dehydrated in ethanol of series concentrations, and embedded in resin. Ultrathin sections $(50-60 \mathrm{~nm})$ were contrasted with lead citrate and uranyl acetate, and then examined under a transmission electron microscope (TEM; H-7650, Hitachi High Technologies Corporation, Tokyo, Japan).

\section{Statistical Analysis}

All reported data were expressed as means or means \pm standard deviations from 3 independent preparations or evaluations. Statistical analysis was performed by using SPSS software version 16.0 (SPSS Inc., Chicago, IL) using one-way ANOVA with Duncan's multiple range tests. The statistical significance was set at a level of $P<0.05$.

\section{RESULTS}

\section{Chemical Features of the 2 Digests}

The SDS-PAGE results (Figure 1) demonstrated caseinate changes during the preparation of glycated caseinate. Protein staining (Figure 1A) showed that the sample in lane 2 consisted of various protein fractions, but some protein fractions in the top of this lane had higher molecular weights than caseinate (in lane 1). This implies that some protein fractions of this sample in lane 2 were cross-linked. Saccharide staining (Figure 1B) indicated that the sample in lane 2 had stronger positive response to the used saccharide staining, proving that this sample contained some glycated proteins. It is thus concluded that the sample in lane 2 was glycated caseinate. That is, caseinate was lactose-glycated during the preparation. When glycated caseinate was subjected to TFA hydrolysis, the resultant hydrolysate was detected to contain galactose. Glycated caseinate was thus calculated with bound lactose content of 14.29 $\mathrm{g} / \mathrm{kg}$ of protein. Glycated caseinate digest was also detected to contain galactose, and calculated with bound lactose content of $13.51 \mathrm{~g} / \mathrm{kg}$ of protein. This result proved that glycated caseinate digest contained some 
Table 1. Amino acid contents ${ }^{1}(\mathrm{~g} / \mathrm{kg}$ of protein) of caseinate digest and glycated caseinate digest

\begin{tabular}{lcc}
\hline AA & Caseinate digest & Glycated caseinate digest \\
\hline Ala & $27.3 \pm 1.2$ & $28.3 \pm 1.5$ \\
Arg & $41.7 \pm 2.1$ & $40.3 \pm 2.2$ \\
Asp & $60.6 \pm 1.8$ & $66.9 \pm 1.8$ \\
Cys & $16.6 \pm 1.1$ & $13.0 \pm 0.9$ \\
Glu & $213.3 \pm 3.7$ & $212.1 \pm 4.1$ \\
Gly & $19.9 \pm 1.6$ & $20.0 \pm 1.8$ \\
His & $29.3 \pm 2.5$ & $25.7 \pm 2.1$ \\
Ile & $54.4 \pm 2.0$ & $54.2 \pm 2.2$ \\
Leu & $94.8 \pm 2.9$ & $94.3 \pm 3.0$ \\
Lys & $82.9 \pm 2.0$ & $70.4 \pm 2.1$ \\
Met & $28.3 \pm 1.5$ & $34.2 \pm 2.3$ \\
Phe & $50.2 \pm 2.7$ & $49.1 \pm 2.6$ \\
Pro & $82.7 \pm 2.9$ & $84.5 \pm 3.5$ \\
Ser & $55.6 \pm 1.1$ & $59.1 \pm 1.6$ \\
Thr & $33.8 \pm 1.6$ & $36.4 \pm 1.9$ \\
Tyr & $58.6 \pm 2.1$ & $55.6 \pm 2.7$ \\
Val & $50.2 \pm 1.9$ & $55.5 \pm 1.8$ \\
\hline
\end{tabular}

${ }^{1}$ Values are reported as means $\pm \mathrm{SD}(\mathrm{n}=3)$.

glycated peptides. After SDS-PAGE analysis, caseinate showed a much weaker positive response to the used saccharide staining (Figure 1B, in lane 1). As it can be expected, both caseinate and caseinate digest after TFA hydrolysis were detected without galactose (i.e., lactose).

Two digest were detected for their contents of $17 \mathrm{AA}$ (Table 1). In comparison with caseinate digest, glycated caseinate digest showed lower contents of several AA, especially Lys, indicating that some sensitive AA such as Lys were damaged during the preparation of glycated caseinate. The damage of these sensitive AA might confer glycated caseinate digest with changed activities compared with caseinate digest.

\section{Growth Proliferation of IEC-6 Cells in Response to 2 Digests}

Caseinate digest and glycated caseinate digest were used at 4 digest concentrations to treat IEC- 6 cells for 6 to $48 \mathrm{~h}$, to assay their effects on cell growth using cell viability values as evaluation index. The cells treated with normal medium were designated as having $100 \%$ viability. Based on the obtained data (Table 2), some results are briefly summarized. Digest concentration of $0.02 \mathrm{~g} / \mathrm{L}$ always ensured 2 digests with higher proliferative effect than using other digest concentrations, whereas treatment times of 12 to $24 \mathrm{~h}$ mostly resulted in higher proliferative effect. Two digests at higher concentrations (e.g., $0.5 \mathrm{~g} / \mathrm{L}$ ) were toxic to the cells and inhibited growth of IEC-6 cells, as the measured values of cell viability were less than $100 \%$. Incubation time of $48 \mathrm{~h}$ also led to weaker proliferative effect. More important, in comparison with caseinate digest,

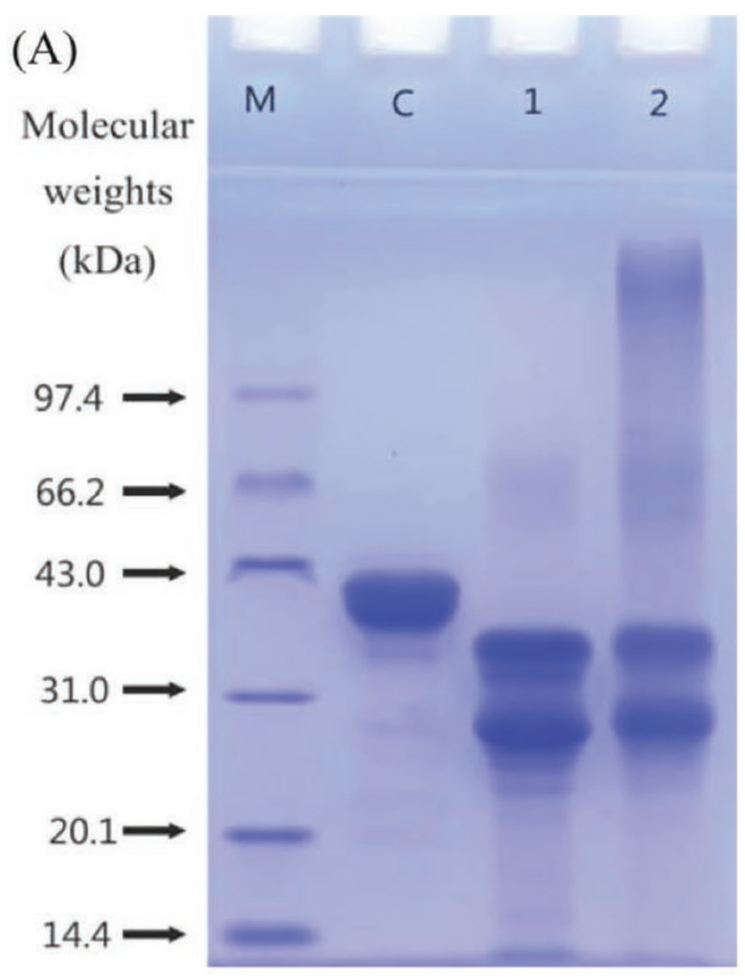

(B)

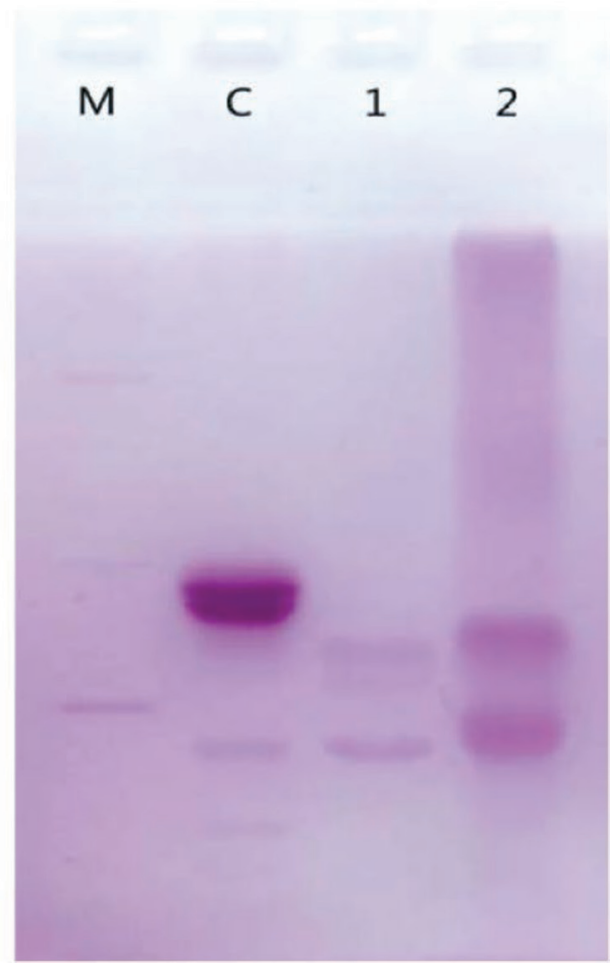

Figure 1. Electrophoretic profiles of the protein samples using protein (A) and saccharide (B) staining, respectively. Lanes 1 and 2, caseinate and glycated caseinate, respectively; lanes $\mathrm{M}$ and $\mathrm{C}$, protein markers and horseradish peroxidase, respectively. Color version available online. 
Table 2. Measured viability ${ }^{1}(\%)$ of the rat intestinal epithelial (IEC-6) cells treated with caseinate digest and glycated caseinate digest

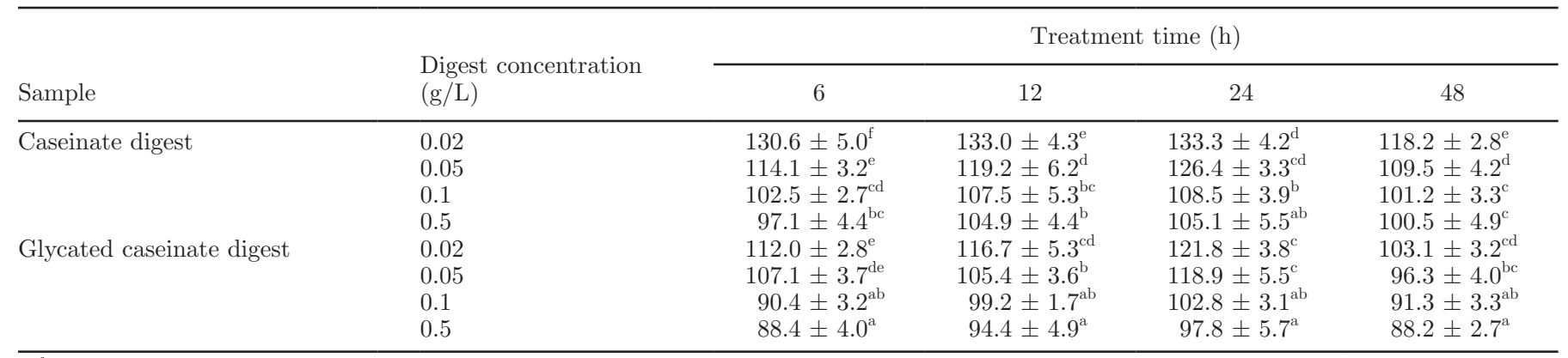

${ }^{\mathrm{a}-\mathrm{f}}$ Means within a column with different superscript letters differ significantly $(P<0.05)$.

${ }^{1}$ Values are reported as means $\pm \mathrm{SD}(\mathrm{n}=3)$.

glycated caseinate digest always caused lower cell viability. Glycated caseinate digest showed slight growth inhibition on IEC- 6 cells even at a digest concentration of $0.1 \mathrm{~g} / \mathrm{L}$, which was not observed in the case of caseinate digest. All these results point out an interesting fact, which is that lactose glycation of caseinate via the Maillard reaction brought damaged cell proliferation to the resultant glycated caseinate digest. Two digests at $0.5 \mathrm{~g} / \mathrm{L}$ inhibited the growth of IEC- 6 cells. This digest concentration was not used in other evaluations of this study. Cell treatment of $6 \mathrm{~h}$ led to less proliferative effect; this treatment time was no longer used in later evaluations.

\section{Anti-Apoptosis of 2 Digests to IEC-6 Cells}

Caseinate digest and glycated caseinate digest were also assessed for their anti-apoptotic activities (i.e., apoptotic prevention) to the cells using flow cytometry technique (Appendix Figures A1 and A2). The data listed in Table 3 summarize measured apoptotic prevention of the 2 digests with a treatment time of $24 \mathrm{~h}$, using total apoptotic proportion (i.e., Q2 + Q4) as assaying index. The IEC-6 cells in the control group were not treated with 2 digests or camptothecin, and showed the lowest total apoptotic proportion (4.6\%). The IEC6 cells in the model group were not treated with 2 digests but only treated with camptothecin, and thus had the highest total apoptotic proportion $(22.3 \%)$. This result proved apoptosis induction of camptothecin to IEC-6 cells. If caseinate digest was used at 0.02 to 0.1 $\mathrm{g} / \mathrm{L}$ of digest concentrations to pretreat the cells before camptothecin treatment, respective total apoptotic proportions were 9.9 to $16.7 \%$. Using glycated caseinate digest at the 3 digest concentrations to pretreat the cells led to total apoptotic proportions of 13.7 to 19.4\%. Two digests both exerted apoptotic prevention on IEC-6 cells via reducing total apoptotic proportion. In general, $0.02 \mathrm{~g} / \mathrm{L}$ of digest concentration resulted in the highest apoptotic prevention $(P<0.05)$, but higher digest concentrations (e.g., $0.05-0.1 \mathrm{~g} / \mathrm{L}$ ) led to decreased apoptotic prevention. Moreover, caseinate digest at each concentration had stronger apoptotic prevention (i.e., resulted in lower total apoptotic proportion) than glycated caseinate digest. Two digests were able to reduce both early apoptotic cells (Q4) and late apoptotic cells (Q2). Regarding model cells, caseinate digest at 3 digest concentrations could decrease early and late apoptotic cell numbers by 19.4 to $64.5 \%$ and 29.2 to $49.2 \%$, respectively; however, glycated caseinate digest at the 3 digest concentrations only lessened the respective cell numbers by 2.2 to $36.6 \%$ and 15.9 to $40.0 \%$. Lactose glycation of caseinate was thus verified to be more harmful to the anti-apoptotic activity to early apoptotic cells.

When 2 digests were used to pretreat IEC- 6 cells for a shorter time (i.e., $12 \mathrm{~h}$ ), they also showed apoptotic prevention (Table 4). The IEC-6 cells in control and model groups had total apoptotic proportions $(\mathrm{Q} 2+$ Q4) of 4.4 and $17.8 \%$, respectively. At 0.02 to $0.1 \mathrm{~g} / \mathrm{L}$ of digest concentrations, caseinate digest resulted in total apoptotic proportions of 10.0 to $15.2 \%$, whereas glycated caseinate digest caused total apoptotic proportions of 13.9 to $16.1 \%$. Digest concentration of $0.02 \mathrm{~g} / \mathrm{L}$ also led to the highest apoptotic prevention, whereas caseinate digest was unexpectedly stronger than glycated caseinate digest to prevent the camptothecin-induced apoptosis. However, apoptotic prevention of 2 digests was mainly reflected by their capacities to reduce the late apoptotic cells (Q2). This phenomenon was partially different from that observed in Tables 3, and should be clarified in another investigation.

In total, 2 digests both had apoptotic prevention on IEC-6 cells, resulting in the treated cells with lower total apoptotic proportions. Caseinate digest in all cases was stronger than glycated caseinate digest to exert apoptotic prevention. This fact indicated that lactose glycation of caseinate via the Maillard reaction ad- 
Table 3. Cell proportions ${ }^{1}$ of rat intestinal epithelial (IEC-6) cells treated with caseinate digest and glycated caseinate digest for $24 \mathrm{~h}$

\begin{tabular}{|c|c|c|c|c|c|}
\hline Cell group & $\begin{array}{l}\text { Digest concentration } \\
(\mathrm{g} / \mathrm{L})\end{array}$ & \multicolumn{4}{|c|}{ Proportion of the cells ${ }^{2}(\%)$} \\
\hline Control cells & None & $0.0 \pm 0.0^{\mathrm{a}}$ & $4.2 \pm 0.4^{\mathrm{a}}$ & $95.4 \pm 0.4^{\mathrm{f}}$ & $0.4 \pm 0.0^{\mathrm{a}}$ \\
\hline Model cells & None & $0.1 \pm 0.0^{\mathrm{a}}$ & $13.0 \pm 0.7^{\mathrm{e}}$ & $77.6 \pm 1.4^{\mathrm{a}}$ & $9.3 \pm 0.7^{\mathrm{e}}$ \\
\hline \multirow[t]{3}{*}{ Cells treated with caseinate digest } & 0.02 & $0.0 \pm 0.0^{\mathrm{a}}$ & $6.6 \pm 0.4^{\mathrm{b}}$ & $90.1 \pm 0.7^{\mathrm{e}}$ & $3.3 \pm 0.3^{\mathrm{b}}$ \\
\hline & 0.05 & $0.0 \pm 0.0^{\mathrm{a}}$ & $8.7 \pm 0.9^{\mathrm{bcd}}$ & $85.8 \pm 1.2^{\mathrm{d}}$ & $5.5 \pm 0.4^{\mathrm{c}}$ \\
\hline & 0.1 & $0.0 \pm 0.0^{\mathrm{a}}$ & $9.2 \pm 0.2^{\mathrm{cd}}$ & $83.3 \pm 0.9^{c}$ & $7.5 \pm 0.7^{\mathrm{d}}$ \\
\hline Cells treated with glycated caseinate digest & 0.1 & $0.1 \pm 0.0^{\mathrm{a}}$ & $10.3 \pm 1.9^{\mathrm{d}}$ & $80.5 \pm 1.1^{\mathrm{b}}$ & $9.1 \pm 0.8^{\mathrm{e}}$ \\
\hline
\end{tabular}

${ }^{\mathrm{a}-\mathrm{f}}$ Means within same column with different superscript letters differ significantly $(P<0.05)$.

${ }^{1}$ Values are reported as means $\pm \mathrm{SD}(\mathrm{n}=3)$.

${ }^{2} \mathrm{Q} 1$ to $\mathrm{Q} 4$ represent the proportions of necrotic, later apoptotic, viable, and early apoptotic cells, respectively.

versely decreased apoptotic prevention of the resultant caseinate digest.

\section{Differentiation of IEC-6 Cells in Response to the 2 Digests}

The results in Table 5 indicated 2 digests had different effects on the activities of the 3 brush border membrane enzymes in terms of lactase, sucrase, and alkaline phosphatase. When IEC-6 cells were incubated for $4 \mathrm{~d}$ with 2 digests at digest concentrations of 0.02 to $0.1 \mathrm{~g} / \mathrm{L}$, respective lactase activities were detected to be 8.0 to 9.0 and 9.3 to $10.6 \mathrm{nmol} / \mathrm{mg}$ of protein per minute. Incubation of $7 \mathrm{~d}$ brought higher lactase activity because respective values of lactase activity were increased into 9.4 to 11.0 and 11.9 to 13.1 $\mathrm{nmol} / \mathrm{mg}$ of protein per minute. Digest concentration of $0.02 \mathrm{~g} / \mathrm{L}$ other than $0.1 \mathrm{~g} / \mathrm{L}$ always led to higher lactase activity. Glycated caseinate digest resulted in higher lactase activities (16.3-26.6\%), in comparison to caseinate digest. Regarding control cells, 2 digests conferred the treated cells with lower lactase activities (8.6-36.0\%). Similar results could also be found using sucrase and alkaline phosphatase as evaluation indices for cell differentiation. In responses to caseinate digest and glycated caseinate digest, IEC-6 cells inoculated for $4 \mathrm{~d}$ had sucrase activities of 34.7 to 41.9 and 44.8 to $51.3 \mathrm{nmol} / \mathrm{mg}$ of protein per minute, respectively. Long-time incubation $(7 \mathrm{~d})$ with caseinate digest and glycated caseinate digest enhanced respective sucrase activities into 41.4 to 52.1 and 54.3 to $65.2 \mathrm{~mol} / \mathrm{mg}$ of protein per minute. Using glycated caseinate digest resulted in 22.4 to $31.2 \%$ higher sucrase activities than using caseinate digest. However, the cells treated with 2 digests had 4.2 to $42.2 \%$ lower sucrase activities than control cells. With an incubation of $4 \mathrm{~d}$, the cells treated with caseinate digest and glycated caseinate digest had alkaline phosphatase activities of 85.3 to 96.6 and 100.1 to $116.9 \mathrm{mU} / \mathrm{mg}$ of protein, respectively; with another incubation time of $7 \mathrm{~d}$, alkaline phosphatase activities were increased into 168.8 to 189.4 and 196.4 to $236.3 \mathrm{mU} / \mathrm{mg}$ of protein, respectively. In comparison with caseinate digest, glycated caseinate digest resulted in 17.4 to $24.8 \%$ activity increases for alkaline phosphatase. Regarding control cells, the cells treated with 2 digests had 5.0 to $36.9 \%$ activity decreases for alkaline

Table 4. Cell proportions ${ }^{1}$ of rat intestinal epithelial (IEC-6) cells treated with caseinate digest and glycated caseinate digest for $12 \mathrm{~h}$

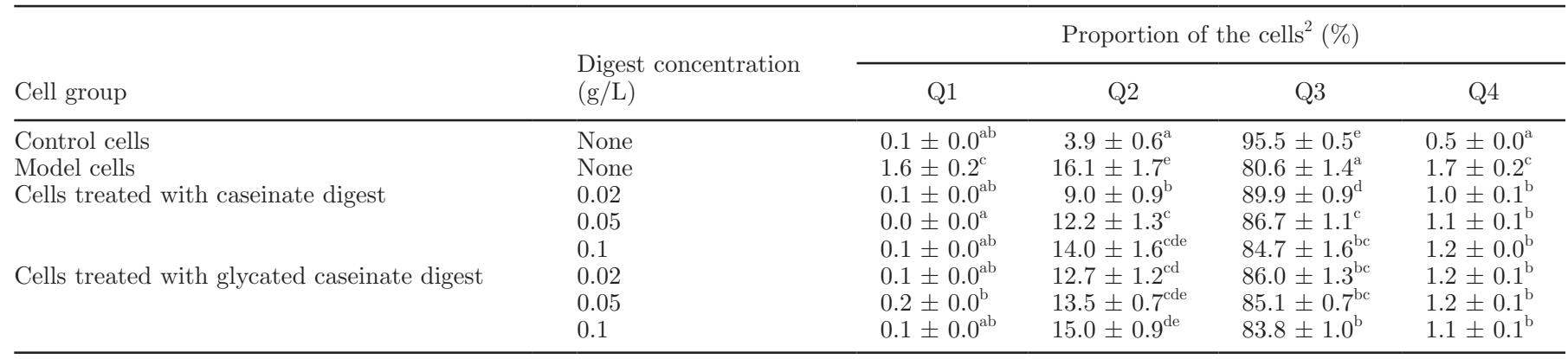

\footnotetext{
${ }^{\mathrm{a}-\mathrm{e}}$ Means within same column with different superscript letters differ significantly $(P<0.05)$.

${ }^{1}$ Values are reported as means $\pm \mathrm{SD}(\mathrm{n}=3)$.

${ }^{2} \mathrm{Q} 1$ to Q4 represent the proportions of necrotic, later apoptotic, viable, and early apoptotic cells, respectively.
} 
Table 5. Measured activities ${ }^{1}$ of 3 enzymes in the differentiated rat intestinal epithelial (IEC-6) cells in response to the treatments using caseinate digest and glycated caseinate digest

\begin{tabular}{|c|c|c|c|c|}
\hline Control cells & 4 & $11.6 \pm 0.4^{\mathrm{d}}$ & $53.6 \pm 2.3^{\mathrm{c}}$ & $123.0 \pm 6.3^{\mathrm{b}}$ \\
\hline \multirow{2}{*}{ Cells treated with caseinate digest of $0.02 \mathrm{~g} / \mathrm{L}$} & 4 & $9.0 \pm 0.4^{\mathrm{ab}}$ & $41.9 \pm 1.6^{\mathrm{b}}$ & $96.9 \pm 2.2^{\mathrm{a}}$ \\
\hline & 7 & $11.0 \pm 0.7^{\mathrm{d}}$ & $52.1 \pm 1.7^{\mathrm{c}}$ & $189.4 \pm 7.0^{\mathrm{d}}$ \\
\hline \multirow[t]{2}{*}{ Cells treated with caseinate digest of $0.1 \mathrm{~g} / \mathrm{L}$} & 4 & $8.0 \pm 0.5^{\mathrm{a}}$ & $34.7 \pm 1.4^{\mathrm{a}}$ & $85.3 \pm 1.6^{\mathrm{a}}$ \\
\hline & 7 & $9.4 \pm 0.5^{\mathrm{bc}}$ & $41.4 \pm 1.9^{\mathrm{b}}$ & $168.8 \pm 6.4^{\mathrm{c}}$ \\
\hline \multirow[t]{2}{*}{ Cells treated with glycated caseinate digest of $0.1 \mathrm{~g} / \mathrm{L}$} & 4 & $9.3 \pm 0.4^{\mathrm{ab}}$ & $44.8 \pm 1.5^{\mathrm{b}}$ & $100.1 \pm 3.1^{\mathrm{a}}$ \\
\hline & 7 & $11.9 \pm 0.5^{\mathrm{de}}$ & $54.3 \pm 2.5^{\mathrm{c}}$ & $196.4 \pm 10.0^{\mathrm{d}}$ \\
\hline
\end{tabular}

\footnotetext{
${ }^{\mathrm{a}-\mathrm{f}}$ Means within a column with different superscript letters differ significantly $(P<0.05)$.
}

${ }^{1}$ Both lactase and sucrase activities are expressed as nanomoles of glucose/milligram of protein per minute, whereas alkaline phosphatase activity is expressed as milliunits/milligram of protein. Values are reported as means $\pm \mathrm{SD}(\mathrm{n}=3)$.

phosphatase. In general, long-time treatment led to much cell differentiation, and glycated caseinate digest was consistently more potent than caseinate digest to promote cell differentiation. This indicates that lactose glycation of caseinate via the Maillard reaction conferred glycated caseinate digest with higher differentiation induction to IEC-6 cells.

With the aid of the classic TEM technique, 2 digests with different capacities were also proven to change external morphology of differentiated IEC-6 cells. The results indicated that the cells with an incubation time of $7 \mathrm{~d}$ showed a polarized morphology and were observed to have microvilli at the apical poles (Figure 2 ). In comparison with the cells treated with 2 digests, control cells were observed to have more microvilli on the surface (Figure 2A vs. Figures $2 \mathrm{~B}$ and $2 \mathrm{C}$ ). These visual results were consistent with those biochemical assaying results about the activities of the 3 brush border membrane enzymes in control cells, as control cells were also detected with the highest enzyme activities (Table 5). When the cells were treated with glycated caseinate digest at digest concentration of $0.02 \mathrm{~g} / \mathrm{L}$, fewer microvilli were observed on the cell surface (Figure 2B). However, if the cells were treated with caseinate digest of same digest concentration, many fewer microvilli were observed on the cell surface (Figure 2C). Using caseinate digest and a shorter incubation time of $4 \mathrm{~d}$, it was hardly possible to observe microvillus formation on the cell surface; however, glycated caseinate digest was observed to be able to induce the formation of fewer microvilli. These results demonstrated that the cells with this incubation time had much weaker differentiation. The TEM observation results proved again that glycated caseinate digest had stronger ability than caseinate digest to induce cell differentiation. Clearly, TEM observation results were consistent with these biochemical assaying results about the 3 brush border membrane enzymes in the treated cells (Table 5).

\section{DISCUSSION}

Milk is an ideal matrix for the Maillard reaction due to its high contents in lactose and milk proteins, and moreover, thermal treatment necessary to milk processing can intensify this reaction (Pischetsrieder and Henle, 2012). In several milk products such as skim milk powder, up to $50 \%$ of the Lys residues are converted into lactulosyl-Lys as the result of this reaction (Henle et al., 1991). This study also showed evidence of AA loss of caseinate digest (Table 1). The modified Lys/ Arg residues are no longer recognized by proteolytic enzymes, this reaction thus exerts adverse effects on the gastrointestinal digestion and nutritional values of milk proteins (Rérat et al., 2002; Dalsgaard et al., 2007). After sterilization as well as drying and long-time storage, this reaction brings changed biological properties for milk and milk-based products, due to the formation of antioxidative, mutagenic, antimutagenic, and less antigenic products (van Boekel, 1998). All these results demonstrate that this reaction indeed has several negative effects on milk and milk products. Dietary components have been documented to influence intestinal development and functions (Perin et al., 1997). This reaction might influence bio-functions of milk and milk-based products, especially potential functions for intestinal epithelial cells. This is an important health and safety issue and should be assessed through both in vitro and in vivo studies. The evidence supporting this study come from 2 previous studies (Zhang et al., 2006; Ibrahim et al., 2011), in which unfavorable effects of the Maillard reaction products (i.e., glucose glycated bovine serum albumin and Amadori-glycated albumin) have been clarified for their roles in the development of 

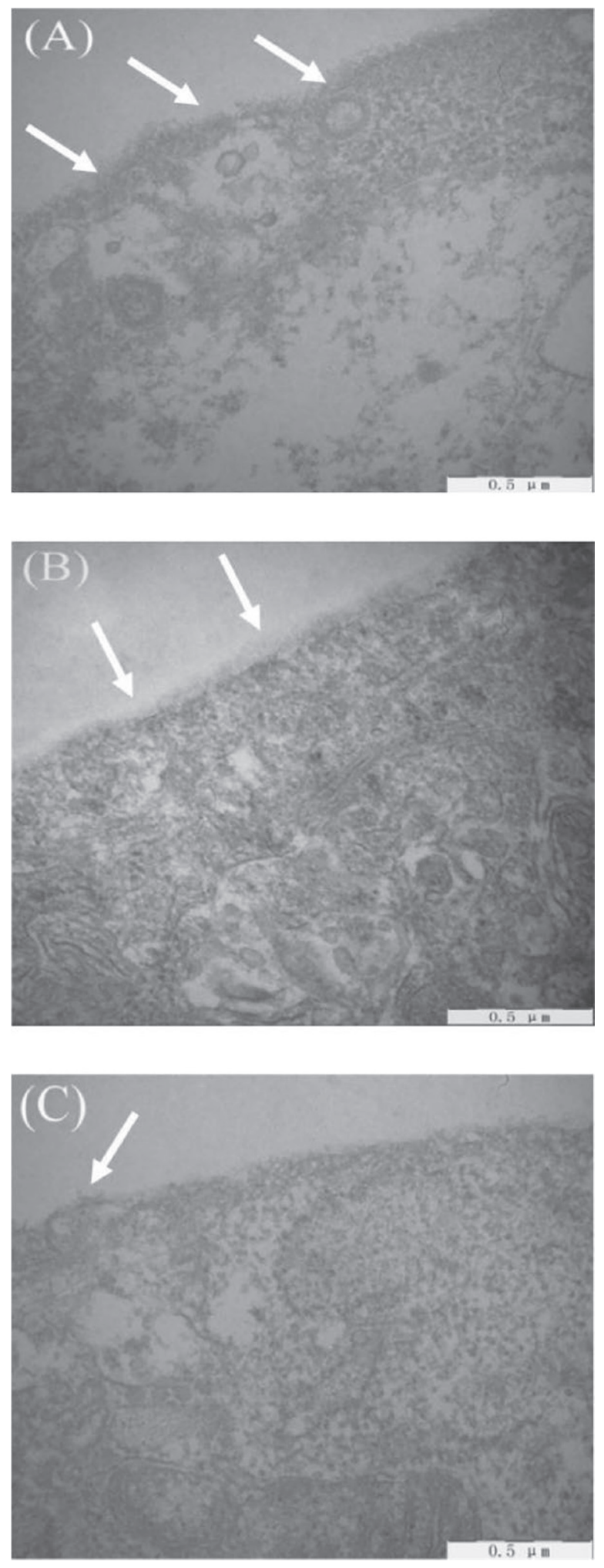

Figure 2. Transmission electron microscopic observation of control rat intestinal epithelial (IEC-6) cells (A) or the cells pretreated with glycated caseinate digest (B) or caseinate digest (C) at $0.02 \mathrm{~g} / \mathrm{L}$ of digest concentration for $7 \mathrm{~d}$. The white arrows show the microvilli of IEC-6 cells as an indication of cell differentiation. The labeled bars are $0.5 \mu \mathrm{m}$. vision loss and heart disease among the patients with diabetes.

The intestinal epithelium has a very dynamic cell population; the enterocytes proliferate in the crypt and migrate toward the villi where they undergo apoptosis (Grishin et al., 2005). The balanced proliferation, migration, and apoptosis are crucial for intestinal homeostasis (Braga-Neto et al., 2012). The IEC-6 cells are nontumorigenic epithelial stem cells retaining their undifferentiated character and therefore are used as a cell model to reveal potential effects of different components (e.g., the products of the Maillard reaction) on the functions of intestine epithelial cells. Glycoprotein extract from Laminaria japonica in a dose-dependent manner show the capacity to promote the growth of IEC-6 cells (Lee et al., 2015). The polysaccharides from Ganoderma lucidum have effective protection on gastrointestinal mucosal function, as they can stimulate the proliferation and migration of IEC-6 cells (Chen et al., 2011). In this study, both caseinate digest and glycated caseinate digest were found with growth proliferation and inhibition on IEC-6 cells. Two digests were detected without apparent toxicity to the cells only at lower digest concentrations (cell viability larger than 100\%); however, 2 digests at $0.5 \mathrm{~g} / \mathrm{L}$ exerted cytotoxicity to the cells via inhibiting cell growth (cell viability less than $100 \%$; Table 2). This finding is supported by the results of other studies. The Maillard reaction products of BSA and methylglyoxal at lower concentrations can promote the growth of the mesangial cells, whereas at higher concentrations they can inhibit cell growth (Geoffroy et al., 2004). In another study using BSA and D-glyceraldehyde or D-glycolaldehyde for the Maillard reaction, the obtained products at higher concentrations display inhibition on human mesenchymal stem cells (Kume et al., 2005). In this study, no cytotoxicity to IEC-6 cells was observed using shorttime treatment $(6-24 \mathrm{~h})$, whereas long-time treatment of $48 \mathrm{~h}$ also led to clear growth inhibition (i.e., cytotoxicity; Table 2). Similar to this finding, the Maillard reaction products of Lys and ribose exert cytotoxic effect on the HeLa cells only after $24 \mathrm{~h}$ (Vagnarelli et al., 1991). Amino acid loss during the Maillard reaction is a well-known event (Arena et al., 2011). Decreased growth proliferation and increased cytotoxicity of glycated caseinate digest might be the result of AA loss during the preparation of glycated caseinate. Some peptides in glycated caseinate digest contained damaged AA (e.g., Lys; Table 1). On the contrary, caseinate digest did not have any amino acid damage. Caseinate digest therefore was considered with better capacity to promote cell growth. The potential effect of the attached lactose moiety on growth proliferation 
of glycated caseinate digest was not assessed in this study, but needs a detailed investigation in future.

Apoptosis is a fundamental event in the regulation of cell numbers in all multicellular organisms, whereas abnormal apoptosis of intestine epithelial cells may lead to gut mucosal dysfunction. Many factors, even dietary components, can influence the apoptosis in intestinal mucosal epithelia. Apoptotic prevention is thus most important to maintain normal intestinal function (Bhattacharya et al., 2004). Fetal bovine serum and aged garlic extract have been proved with ability to inhibit the apoptosis of IEC-6 cells (Hung et al., 2004; Li et al., 2009). In the recent years, several protein hydrolysates have been proved able to exert anti-apoptotic activities to osteoblastic cells (Fu and Zhao, 2013; Pan and Zhao, 2015). Less attention has been paid to anti-apoptotic activities of protein digests to intestinal epithelial cells. To our knowledge, the Maillard reaction products have been assessed for their apoptosis induction to other cells. The Maillard reaction product from fructose and tyrosine can inhibit the growth of colon cancer cells, followed by apoptosis induction (Ban et al., 2014). Amadori adducts (i.e., glycated hemoglobin or BSA) can induce apoptosis of human peritoneal mesothelial cells in a time-dependent manner via regulating the intrinsic mitochondrial cell death signaling pathway (Sánchez-Rodríguez et al., 2011). These results show that the Maillard reaction might lead to higher apoptosis induction (i.e., lower anti-apoptotic effect) of the resultant products. In this study, both caseinate digest and glycated caseinate digest showed anti-apoptotic effects on IEC-6 cells; however, lactose glycation of caseinate was revealed to reduce the anti-apoptotic effect of glycated caseinate digest (Tables 3 and 4). It is thus concluded that prior lactose glycation of caseinate via the Maillard reaction was also an unfavorable event, regarding anti-apoptotic effects of protein digests. Loss of EAA (especially Lys) during the preparation of glycated caseinate might be a key factor to confer glycated caseinate digest with reduced anti-apoptotic effect.

Differentiation is a complicated and precise process in the life cycle of cells. Many exogenous factors including dietary components can influence this process. For example, lactoferrin (a glycoprotein in milk) is able to increase the differentiation of intestinal epithelial cells (Blais et al., 2014). The Maillard reaction has also been assessed for its influences on the differentiation of several cells. The Maillard reaction products from BSA and ribose can inhibit the differentiation of osteoblasts and osteoclasts, and therefore decrease osteoclastinduced bone resorption (Valcourt et al., 2007). Bread crust extract, which contains significant amounts of a variety of the Maillard reaction products, can inhibit the differentiation of mice cardiac myofibroblast via reducing the expression of smooth muscle $\alpha$-actin and tropomyosin-1 (Ruhs et al., 2007). Advanced glycation end products of BSA and glycolaldehyde are able to prevent human mesenchymal stem cells from differentiating into adipocytes and chondrocytes, but promote osteogenic differentiation via increasing alkaline phosphatase activity (Kume et al., 2005). The Maillard reaction products seem able to decrease or increase the differentiation of various cells. However, the effects of the Maillard reaction products on the differentiation of intestinal epithelial cells were not well assessed in the past. This study might show for first time that the Maillard reaction conferred glycated caseinate digest with enhanced differentiation induction (Table 5 and Figure 2). The possible reason was not clarified in this study, but might involve the different compositions of caseinate digest and glycated caseinate digest because glycated caseinate digest contained some glycated peptides. Glycated caseinate digest showed higher differentiation induction than caseinate digest toward IEC-6 cells, indicating that glycated caseinate digest might interfere with the cellular differentiation processes in a rather specific manner. Special attention should be paid to this underlying manner.

Potential effects of lactose glycation of caseinate via the Maillard reaction on intestinal epithelial cells were confirmed using glycated caseinate digest and a series of cell experiments. In comparison with caseinate digest, glycated caseinate digest was more toxic to IEC-6 cells, had decreased proliferative and anti-apoptotic effects, but stronger differentiation induction. This finding might provide an important clue about other (mostly unfavorable) effects of this reaction on the activities of milk proteins toward intestinal epithelial cells and even the intestine itself. Further research is suggested to elucidate underlying molecular mechanisms mediating the 3 activities of glycated caseinate digest. Moreover, it should also be investigated whether glycated caseinate from other reducing sugars has similar effects on IEC-6 cells.

\section{CONCLUSIONS}

The results of this study highlight that unavoidable lactose glycation of milk proteins via the Maillard reaction might have new effects on bio-functions of milk and milk-based products. Lactose glycation of caseinate results in glycated caseinate digest with changed in vitro activities toward intestinal epithelial cells compared with normal caseinate digest, including higher cytotoxicity, lower growth proliferation and apoptotic prevention, but higher differentiation induction. Amino acid damage and lactose conjugation during the reaction are suggested to partially contribute to these changed ac- 
tivities. Protein glycation with other reducing saccharides via the Maillard reaction should be investigated to confirm these effects.

\section{ACKNOWLEDGMENTS}

This study was funded by the National High Technology Research and Development Program ("863" Program) of China (project no. 2013AA102205). The authors thank the anonymous reviewers and editors for their valuable advice.

\section{REFERENCES}

AOAC International. 2005. Official Methods of Analysis. 18th ed. AOAC International, Gaithersburg, MD.

Arena, S., G. Renzone, G. Novi, and A. Scaloni. 2011. Redox proteomics of fat globules unveils broad protein lactosylation and compositional changes in milk samples subjected to various technological procedures. J. Proteomics 74:2453-2475.

Arena, S., A. M. Salzano, G. Renzone, C. D. Ambrosio, and A. Scaloni. 2014. Non-enzymatic glycation and glycoxidation protein products in foods and diseases: An interconnected, complex scenario fully open to innovative proteomic studies. Mass Spectrom. Rev. 33:49-77.

Ban, J. O., Y. S. Jung, D. H. Kim, K. R. Park, H. M. Yun, N. J. Lee, H. P. Lee, J. H. Shim, H. S. Jeong, Y. H. Lee, Y. W. Ham, S. B. Han, and J. T. Hong. 2014. (E)-2,4-Bis(p-hydroxyphenyl)-2-butenal inhibits tumor growth via suppression of NF- $\kappa \mathrm{B}$ and induction of death receptor 6. Apoptosis 19:165-178.

Bhatt, H., A. Cucheval, C. Coker, H. Patel, A. Carr, and R. Bennett. 2014. Effect of lactosylation on plasmin-induced hydrolysis of $\beta$-casein. Int. Dairy J. 38:213-218.

Bhattacharya, S., R. M. Ray, and L. R. Johnson. 2004. Prevention of TNF- $\alpha$-induced apoptosis in polyamine-depleted IEC-6 cells is mediated through the activation of ERK1/2. Am. J. Physiol. Gastro. L. 286:479-490.

Blais, A., C. Fan, T. Voisin, N. Aattouri, M. Dubarry, F. Blachier, and D. Tomé. 2014. Effects of lactoferrin on intestinal epithelial cell growth and differentiation: An in vivo and in vitro study. Biometals $27: 857-874$.

Braga-Neto, M. B., B. M. C. Oliveira, R. S. Rodrigues, F. J. Noronha, R. F. Leitao, G. A. C. Brito, A. A. Lima, R. L. Guerrant, and C. A. Warren. 2012. Protective effects of alanyl-glutamine supplementation against nelfinavir-induced epithelial impairment in IEC-6 cells and in mouse intestinal mucosa. Cancer Biol. Ther. 13:1482-1490.

Buccigrossi, V., G. de Marco, E. Bruzzese, L. Ombrato, I. Bracale, G. Polito, and A. Guarino. 2007. Lactoferrin induces concentrationdependent functional modulation of intestinal proliferation and differentiation. Pediatr. Res. 61:410-414.

Chen, L. H., Z. B. Lin, and W. D. Li. 2011. Ganoderma lucidum polysaccharides reduce methotrexate-induced small intestinal damage in mice via induction of epithelial cell proliferation and migration. Acta Pharmacol. Sin. 32:1505-1512.

Chevalier, F., J. M. Chobert, Y. Popineau, M. G. Nicolas, and T. Haertlé. 2011. Improvement of functional properties of $\beta$-lactoglobulin glycated through the Maillard reaction is related to the nature of the sugar. Int. Dairy J. 11:145-152.

Chung, H. K., J. N. Rao, T. T. Zou, L. Liu, L. Xiao, H. Gu, D. J. Turner, P. X. Yang, and J. Y. Wang. 2014. Jnk2 deletion disrupts intestinal mucosal homeostasis and maturation by differentially modulating RNA-binding proteins $\mathrm{HuR}$ and CUGBP1. Am. J. Physiol. Cell Physiol. 306:1167-1175.

Corzo-Martínez, M., O. Hernandez-hernandez, M. Villamiel, R. A. Rastall, and F. J. Moreno. 2013. In vitro bifidogenic effect of Mail- lard-type milk protein-galactose conjugates on the human intestinal microbiota. Int. Dairy J. 31:127-131.

Dalsgaard, T. K., J. H. Nielsen, and L. B. Larsen. 2007. Proteolysis of milk proteins lactosylated in model systems. Mol. Nutr. Food Res. 51:404-414.

Davidek, T., N. Clety, S. Aubin, and I. Blank. 2002. Degradation of the Amadori compound N-(1-deoxy-d-fructos-1-yl) glycine in aqueous model systems. J. Agric. Food Chem. 50:5472-5479.

Dong, S. Y., A. Panya, M. Y. Zeng, B. C. Chen, D. J. Mcclements, and E. A. Decker. 2012. Characteristics and antioxidant activity of hydrolyzed $\beta$-lactoglobulin-glucose maillard reaction products. Food Res. Int. 46:55-61.

Erbersdobler, H. F., and V. Faist. 2001. Metabolic transit of Amadori products. Nahrung/Food 45:177-181.

$\mathrm{Fu}, \mathrm{Y}$., and X. H. Zhao. 2013. In vitro responses of hFOB 1.19 cells towards chum salmon (Oncorhynchus keta) skin gelatin hydrolysates in cell proliferation, cycle progression and apoptosis. J. Funct. Foods 5:279-288.

Geoffroy, K., N. Wiernsperger, M. Lagarde, and S. E. Bawab. 2004. Bimodal effect of advanced glycation end products on mesangial cell proliferation is mediated by neutral ceramidase regulation and endogenous sphingolipids. J. Biol. Chem. 279:34343-34352.

Goldstein, R., T. Klein, S. Freier, and J. Menczel. 1971. Alkaline phosphatase and disaccharidase activities in the rat intestine from birth to weaning. I. Effect of diet on enzyme development. Am. J. Clin. Nutr. 24:1224-1231.

Graves, C. L., S. W. Harden, M. Lapato, M. Nelson, B. Amador, H. Sorenson, C. J. Frazier, and S. M. Wallet. 2014. A method for high purity intestinal epithelial cell culture from adult human and murine tissues for the investigation of innate immune function. J. Immunol. Methods 414:20-31.

Grishin, A., H. Ford, J. Wang, H. Li, V. Salvador-Recatala, E. S. Levitan, and E. Zaks-Makhina. 2005. Attenuation of apoptosis in enterocytes by blockade of potassium channels. Am. J. Physiol. Gastr. L. 289:815-821.

He, Y., S. H. W. Chu, and W. A. Walker. 1993. Nucleotide supplements alter proliferation and differentiation of cultured human (Caco-2) and rat (IEC-6) intestinal epithelial cells. J. Nutr. 123:1017-1027.

Hellwig, M., R. Matthes, A. Peto, J. Löbner, and T. Henle. 2014. N-عfructosyllysine and $n-\varepsilon$-carboxymethyllysine, but not lysinoalanine, are available for absorption after simulated gastrointestinal digestion. Amino Acids 46:289-299.

Henle, T., and T. Miyata. 2003. Advanced glycation end products in uremia. Adv. Ren. Replace. Ther. 10:321-331.

Henle, T., H. Walter, and H. Klostermeyer. 1991. Evaluation of the extent of the early Maillard-reaction in milk products by direct measurement of the Amadori-product lactuloselysine. Z. Lebensm. Unters. Forsch. A. 193:119-122

Hung, W. T., Y. Chen, S. H. Tseng, H. L. Li, and C. K. Chen. 2004. Fetal bovine serum suppresses apoptosis in the small intestine after total ischemia and reperfusion in mice. J. Pediatr. Surg. 39:1077-1083.

Ibrahim, A. S., A. B. El-Remessy, S. Matragoon, W. B. Zhang, Y. Patel, S. Khan, M. M. Al-Gayyar, M. M. El-Shishtawy, and G. I. Liou. 2011. Retinal microglial activation and inflammation induced by amadori-glycated albumin in a rat model of diabetes. Diabetes 60:1122-1133.

Kume, S., S. Kato, S. I. Yamagishi, Y. Inagaki, S. Ueda, N. Arima, T. Okawa, M. Kojiro, and K. Nagata. 2005. Advanced glycation endproducts attenuate human mesenchymal stem cells and prevent cognate differentiation into adipose tissue, cartilage, and bone. J. Bone Miner. Res. 20:1647-1658.

Lee, M. K., I. H. Kim, Y. H. Choi, and T. J. Nam. 2015. A peptide from Porphyra yezoensis stimulates the proliferation of IEC-6 cells by activating the insulin-like growth factor I receptor signaling pathway. Int. J. Mol. Med. 35:533-538.

Li, T., K. Ito, S. Sumi, T. Fuwa, and T. Horie. 2009. Protective effect of aged garlic extract (AGE) on the apoptosis of intestinal epithelial cells caused by methotrexate. Cancer Chemother. Pharmacol. $63: 873-880$ 
Losso, J. N. 2015. Healthy gut, healthy life. Pages 315-329 in The Maillard Reaction Reconsidered. CRC Press, Boca Raton, FL.

Mehta, B. M., and H. C. Deeth. 2016. Blocked lysine in dairy products: Formation, occurrence, analysis, and nutritional implications. Compr. Rev. Food Sci. Food Safety 15:206-218.

Morales, F. J., and S. Jiménez-Pérez. 1998. Study of hydroxymethylfurfural formation from acid degradation of the Amadori product in milk-resembling systems. J. Agric. Food Chem. 46:3885-3890.

Pan, X. W., and X. H. Zhao. 2015. In vitro proliferation and antiapoptosis of the papain-generated casein and soy protein hydrolysates towards osteoblastic cells (hFOB 1.19). Int. J. Mol. Sci 16:13908-13920.

Perin, N. M., M. T. Clandinin, and A. B. R. Thomson. 1997. Importance of milk and diet on the ontogeny and adaptation of the intestine. J. Pediatr. Gastr. Nutr. 24:419-425.

Peterson, L. W., and D. Artis. 2014. Intestinal epithelial cells: Regulators of barrier function and immune homeostasis. Nat. Rev. Immunol. 14:141-153.

Pischetsrieder, M., and T. Henle. 2012. Glycation products in infant formulas: Chemical, analytical and physiological aspects. Amino Acids 42:1111-1118.

Potten, C. S., M. Kellett, D. A. Rew, and S. A. Roberts. 1992. Proliferation in human gastrointestinal epithelium using bromodeoxyuridine in vivo: Data for different sites, proximity to a tumour, and polyposis coli. Gut 33:524-529

Račaitytè, K., S. Kiessig, and F. Kálmán. 2005. Application of capillary zone electrophoresis and reversed-phase high-performance liquid chromatography in the biopharmaceutical industry for the quantitative analysis of the monosaccharides released from a highly glycosylated therapeutic protein. J. Chromatogr. A 1079:354-365.

Rérat, A., R. Calmes, P. Vaissade, and P. A. Finot. 2002. Nutritional and metabolic consequences of the early Maillard reaction of heat treated milk in the pig. Significance for man. Eur. J. Nutr. 41:1-11.

Rufián-Henares, J. A., E. Guerra-Hernández, and B. García-Villanova. 2006. Available lysine and fluorescence in heated milk proteins/ dextrinomaltose or lactose solutions. Food Chem. 98:685-692.

Ruhs, S., N. Nass, V. Somoza, U. Friess, R. Schinzel, R. E. Silber, and A. Simm. 2007. Maillard reaction products enriched food extract reduce the expression of myofibroblast phenotype markers. Mol. Nutr. Food Res. 51:488-495.

Sánchez-Rodríguez, C., C. Peiró, S. Vallejo, N. Matesanz, M. El-Assar, V. Azcutia, T. Romacho, C. F. Sánchez-Ferrer, L. RodríguezMañas, and J. Nevado. 2011. Pathways responsible for apoptosis resulting from amadori-induced oxidative and nitrosative stress in human mesothelial cells. Am. J. Nephrol. 34:104-114.

Schalkwijk, C. G., and T. Miyata. 2012. Early- and advanced nonenzymatic glycation in diabetic vascular complications: The search for therapeutics. Amino Acids 42:1193-1204.

Seiquer, I., J. Díaz-Alguacil, C. Delgado-Andrade, M. López-Frías, A. M. Hoyos, G. Galdó, and M. P. Navarro. 2006. Diets rich in Maillard reaction products affect protein digestibility in adolescent males aged 11-14 y. Am. J. Clin. Nutr. 83:1082-1088.
Seo, S., S. Karboune, and A. Archelas. 2014. Production and characterisation of potato patatin-galactose, galactooligosaccharides, and galactan conjugates of great potential as functional ingredients. Food Chem. 158:480-489.

Siciliano, R. A., M. F. Mazzeo, S. Arena, G. Renzone, and A. Scaloni. 2013. Mass spectrometry for the analysis of protein lactosylation in milk products. Food Res. Int. 54:988-1000.

Silván, J. M., S. H. Assar, C. Srey, M. D. del Castillo, and J. M. Ames. 2011. Control of the Maillard reaction by ferulic acid. Food Chem. 128:208-213.

Song, C. L., and X. H. Zhao. 2014. Structure and property modification of an oligochitosan- glycosylated and crosslinked soybean protein generated by microbial transglutaminase. Food Chem. 163:114-119.

Sun, Y. X., S. Hayakawa, S. Puangmanee, and K. Izumori. 2006. Chemical properties and antioxidative activity of glycated $\alpha$-lactalbumin with a rare sugar, D-allose, by Maillard reaction. Food Chem. 95:509-517.

Tang, C. H., L. Chen, and C. Y. Ma. 2009. Thermal aggregation, amino acid composition and in vitro, digestibility of vicilin-rich protein isolates from three Phaseolus legumes: A comparative study. Food Chem. 113:957-963.

Teodorowicz, M., D. Swiątecka, H. Savelkoul, H. Wichers, and E. Kostyra. 2014. Hydrolysates of glycated and heat treated peanut $7 \mathrm{~S}$ globulin (Ara h 1) modulate human gut microbiota proliferation, survival and adhesion. J. Appl. Microbiol. 116:424-434.

Vagnarelli, P., A. D. Sario, M. T. Cuzzoni, P. Mazza, and L. D. Carli 1991. Cytotoxicity and clastogenic activity of ribose-lysine browning model system. J. Agric. Food Chem. 39:2237-2239.

Valcourt, U., B. Merle, E. Gineyts, S. Viguet-Carrin, P. D. Delmas, and P. Garnero. 2007. Non-enzymatic glycation of bone collagen modifies osteoclastic activity and differentiation. J. Biol. Chem. 282:5691-5703.

van Boekel, M. A. J. S. 1998. Effect of heating on Maillard reactions in milk. Food Chem. 62:403-414.

Wang, Q., and B. Ismail. 2012. Effect of Maillard-induced glycosylation on the nutritional quality, solubility, thermal stability and molecular configuration of whey protein. Int. Dairy J. 25:112-122.

Wang, X. P., and X. H. Zhao. 2016. Using an enzymatic galactose assay to detect lactose glycation extents of two proteins caseinate and soybean protein isolate via the Maillard reaction. J. Sci. Food Agric. https://doi.org/10.1002/jsfa.8084.

Zacharius, R. M., T. E. Zell, J. H. Morrison, and J. J. Woodlock. 1969 Glycoprotein staining following electrophoresis on acrylamide gels Anal. Biochem. 30:148-152.

Zhang, M., A. L. Kho, N. Anilkumar, R. Chibber, P. J. Pagano, A. M. Shah, and A. C. Cave. 2006. Glycated proteins stimulate reactive oxygen species production in cardiac myocytes: Involvement of Nox2 (gp91phox)-containing NADPH oxidase. Circulation 113:1235-1243. 


\section{APPENDIX}
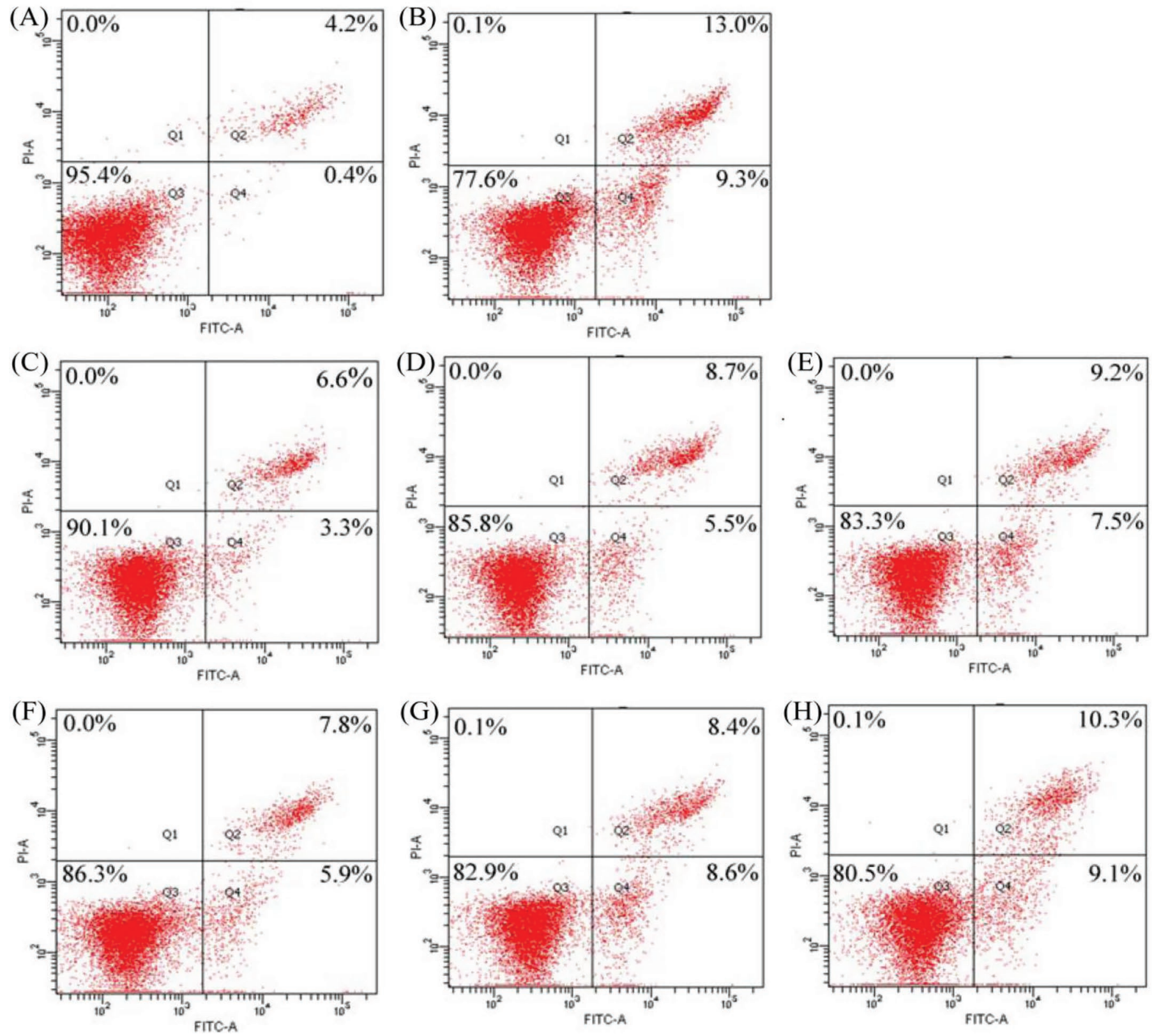

Figure A1. Apoptotic proportions of rat intestinal epithelial (IEC-6) cells subjected to different treatments. (A) Control cells; (B) model cells treated with camptothecin; ( $\mathrm{C}$ to $\mathrm{E}$ ) the cells pretreated with caseinate digest at $0.02,0.05$, and 0.1 gs/L of digest concentration for 24 $\mathrm{h}$, respectively; ( $\mathrm{F}$ to $\mathrm{H}$ ) the cells pretreated with glycated caseinate digest at $0.02,0.05$, and $0.1 \mathrm{~g} / \mathrm{L}$ of digest concentration for $24 \mathrm{~h}$, respectively. The Q1 to Q4 represent the proportions of necrotic, later apoptotic, viable, and early apoptotic cells, respectively. FITC-A = annexin V-fluorescein isothiocyanate. PI-A = annexin V-propidium iodide. Color version available online. 

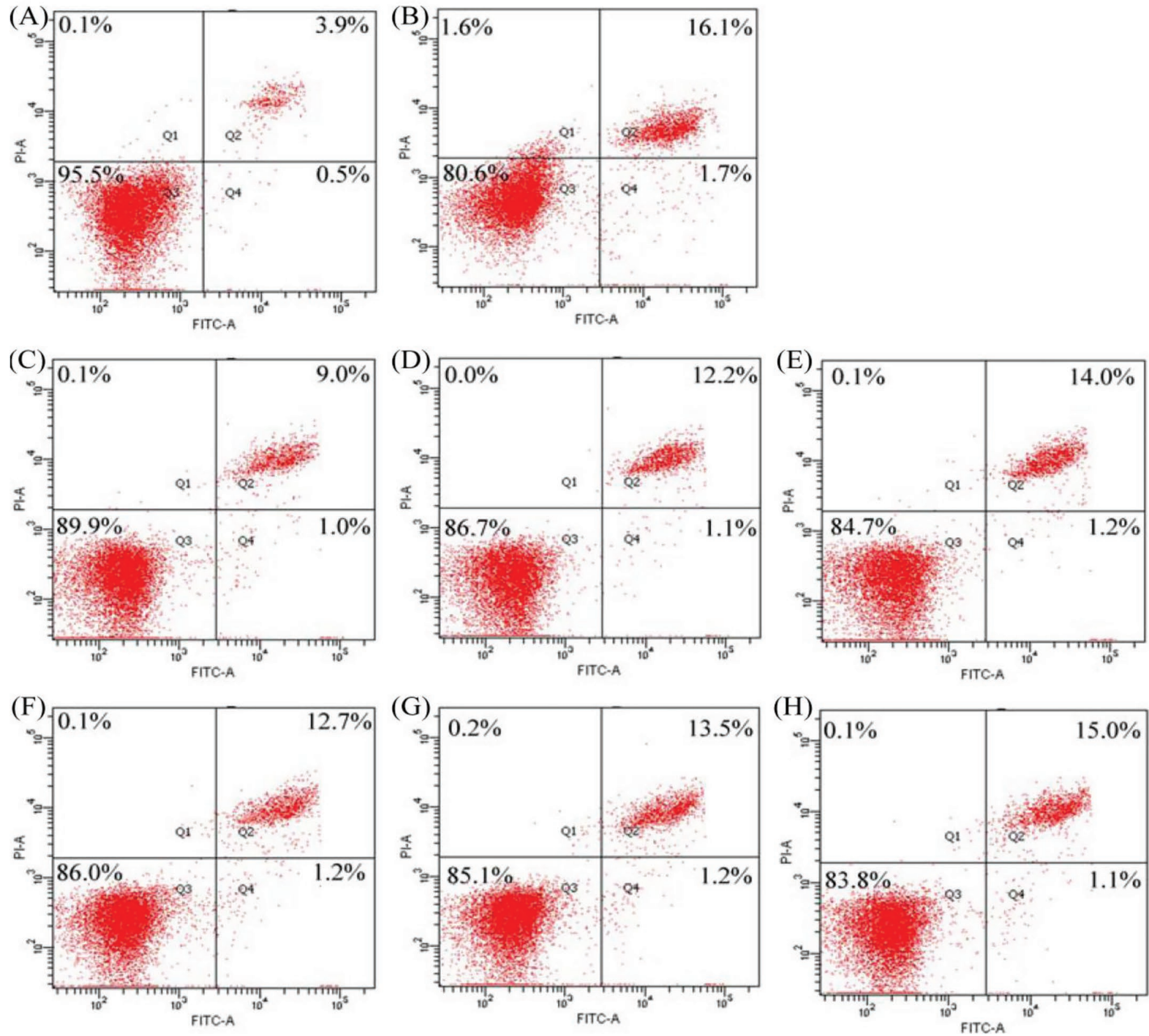

Figure A2. Apoptotic proportions of rat intestinal epithelial (IEC-6) cells subjected to different treatments. (A) Control cells; (B) model cells treated with camptothecin; $(\mathrm{C}$ to $\mathrm{E}$ ) the cells pretreated with caseinate digest at $0.02,0.05$, and $0.1 \mathrm{~g} / \mathrm{L}$ of digest concentrations for 12 $\mathrm{h}$, respectively; $(\mathrm{F}$ to $\mathrm{H}$ ) the cells pretreated with glycated caseinate digest at $0.02,0.05$, and $0.1 \mathrm{~g} / \mathrm{L}$ of digest concentrations for $12 \mathrm{~h}$, respectively. The Q1 to Q4 represent the proportions of necrotic, later apoptotic, viable, and early apoptotic cells, respectively. FITC-A = annexin V-fluorescein isothiocyanate. PI-A = annexin V-propidium iodide. Color version available online. 